\title{
LUDNOŚĆ, ZATRUDNIENIE, MIGRACJE WŚRÓD LUDNOŚCI WIEJSKIEJ ŚLĄSKA OPOLSKIEGO W LATACH 1995-2017-2035
}

\author{
POPULATION, EMPLOYMENT AND MIGRATION \\ OF THE OPOLSKIE VOIVODSHIP'S RURAL POPULATION \\ IN YEARS 1995-2017-2035
}

\author{
Robert RAUZIŃSKI • Kazimierz SZCZYGIELSKI \\ Politechnika Opolska \\ Wydział Ekonomii i Zarządzania \\ ul. Luboszycka 7, 45-036 Opole \\ r.rauzinski@po.opole.pl•k.szczygielski@po.opole.pl
}

\begin{abstract}
Zarys treści: W artykule analizuje się przemiany społeczno-demograficzne i zawodowe ludności wiejskiej województwa opolskiego w okresie 1995-2011, opierając się głównie na danych GUS pochodzących z Narodowych Spisów Powszechnych. Wskazano również skutki tych zjawisk w perspektywie lat 2035 i 2050. Wykazano, że teza o głębokim kryzysie demograficznym wsi opolskiej jest uzasadniona. Zachodzą tu głębokie zmiany w strukturze zawodowej ludności wiejskiej, a wykorzystanie zasobów pracy jest silnie zróżnicowane i złożone, zarówno w ujęciu czasowym, jak i przestrzennym.

Obszary wiejskie o charakterze rolniczym w województwie opolskim nie są w pełni wykorzystane z punktu widzenia potencjału demograficznego, a badania potwierdziły, że czynnik ludzki w rolnictwie słabnie (powstają poważne deformacje demograficzne m.in. z powodu permanentnego odpływu migracyjnego).
\end{abstract}

Słowa kluczowe: ludność wiejska, migracje, Śląsk Opolski.

\section{Wprowadzenie}

Ludność wiejska Śląska Opolskiego charakteryzuje się znacznie wyższym niż w innych obszarach kraju odsetkiem ludności pozarolniczej, dużym zróżnicowaniem etnicznym, masową emigracją zagraniczną, wyludnianiem się licznych gmin, wsi, obszarów przygranicznych, a także trwałymi zaburzeniami w ruchu naturalnym. Celem artykułu jest uzasadnienie tezy, że następuje osłabienie kapitału ludzkiego i społecznego na wsi opolskiej oraz wyraźnie pogłębiający się kryzys demograficzny. W artykule zawarto analizę przemian społeczno-demograficznych i zawodowych ludności wiejskiej w czasie i przestrzeni (1995-2002-2011), opierając się głównie na danych GUS pochodzących z Narodowych Spisów Powszechnych. Na podstawie danych demograficznych zawartych w rocznikach statystycznych opracowano mapy obrazujące zmiany w rozmieszczeniu ludności w gminach (68) wiejskich woje- 
wództwa opolskiego, przyrostu naturalnego ludności w tych gminach w latach 1995-2008, przyrostu (spadku) rzeczywistego ludności w latach 1995-2010, przyrostu rzeczywistego lub spadku ludności w latach 2002-2011, udziału ludności w wieku przedprodukcyjnym, produkcyjnym i poprodukcyjnym w 2010 r., a także salda migracji zagranicznych w latach 1974-2010 (jako udziału w ogólnej liczbie ludności, por. ryc. 1-4).

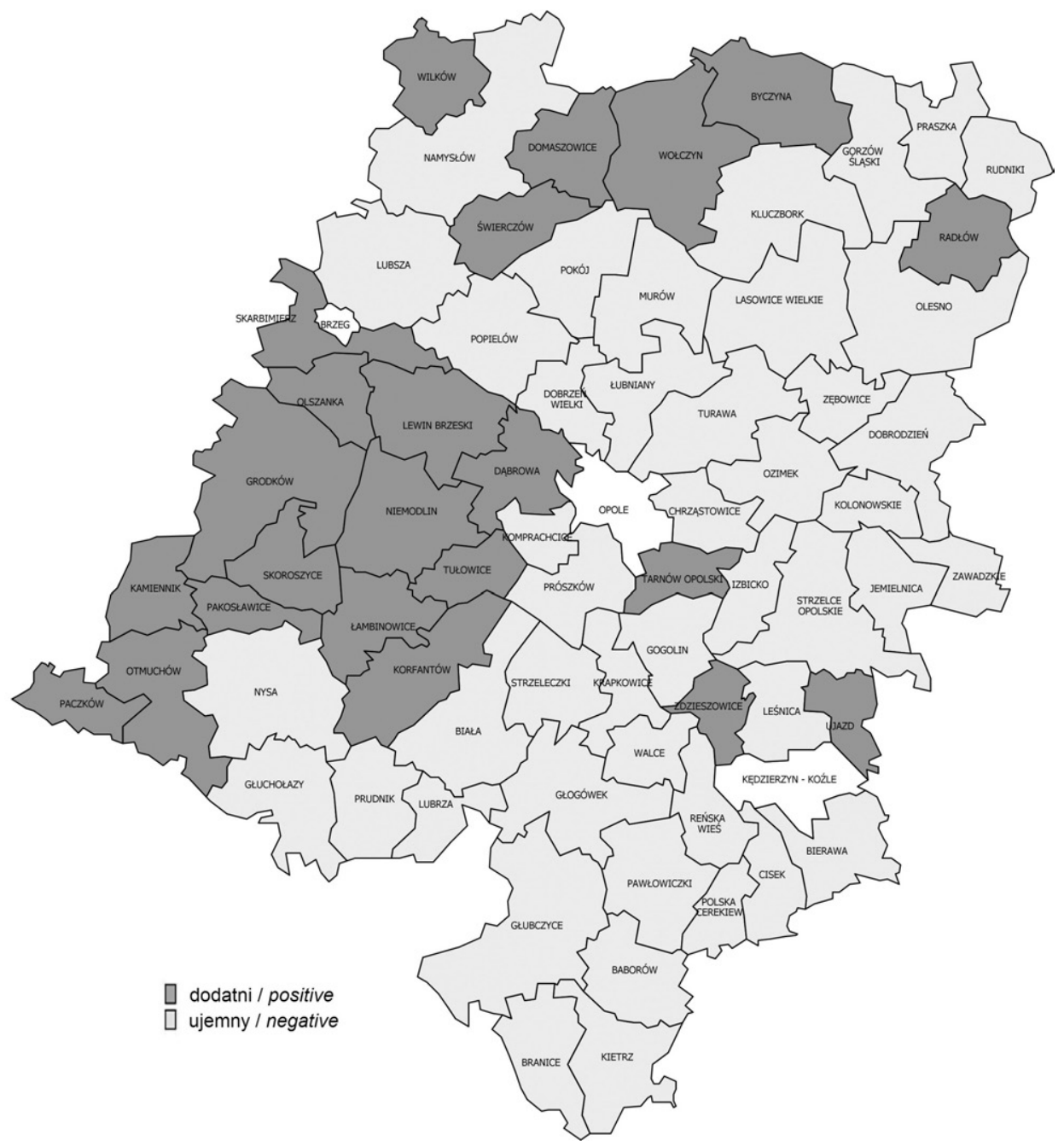

Ryc. 1. Przyrost naturalny na 1000 mieszkańców na wsi w gminach w latach 1995-2008 Natural increase per 1,000 inhabitants in rural communes between 1995 and 2008 Źródło: opracowanie własne R. Rauziński i R. Brzozowski na podstawie Roczników Statystycznych. Source: Own compilation by R. Rauziński and R. Brzozowski based on Statistical Yearbooks 


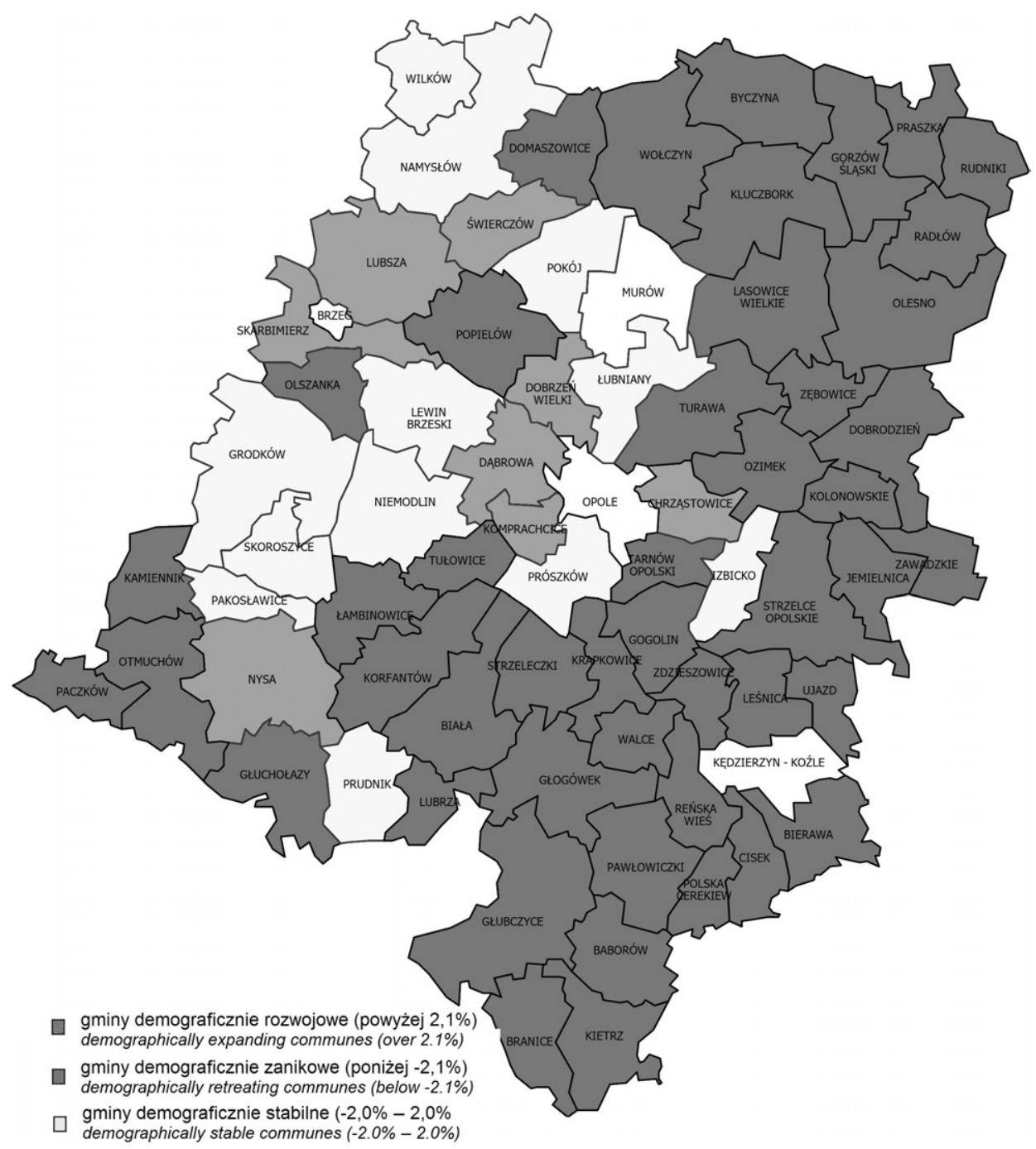

Ryc. 2. Wzrost lub spadek ludności na wsi w latach 1995-2010

Growth or decline of population in rural areas between 1995 and 2010

Źródło: opracowanie własne R. Rauziński i R. Brzozowski na podstawie Roczników Statystycznych. Source: Own compilation by R. Rauziński and R. Brzozowski based on Statistical Yearbooks 


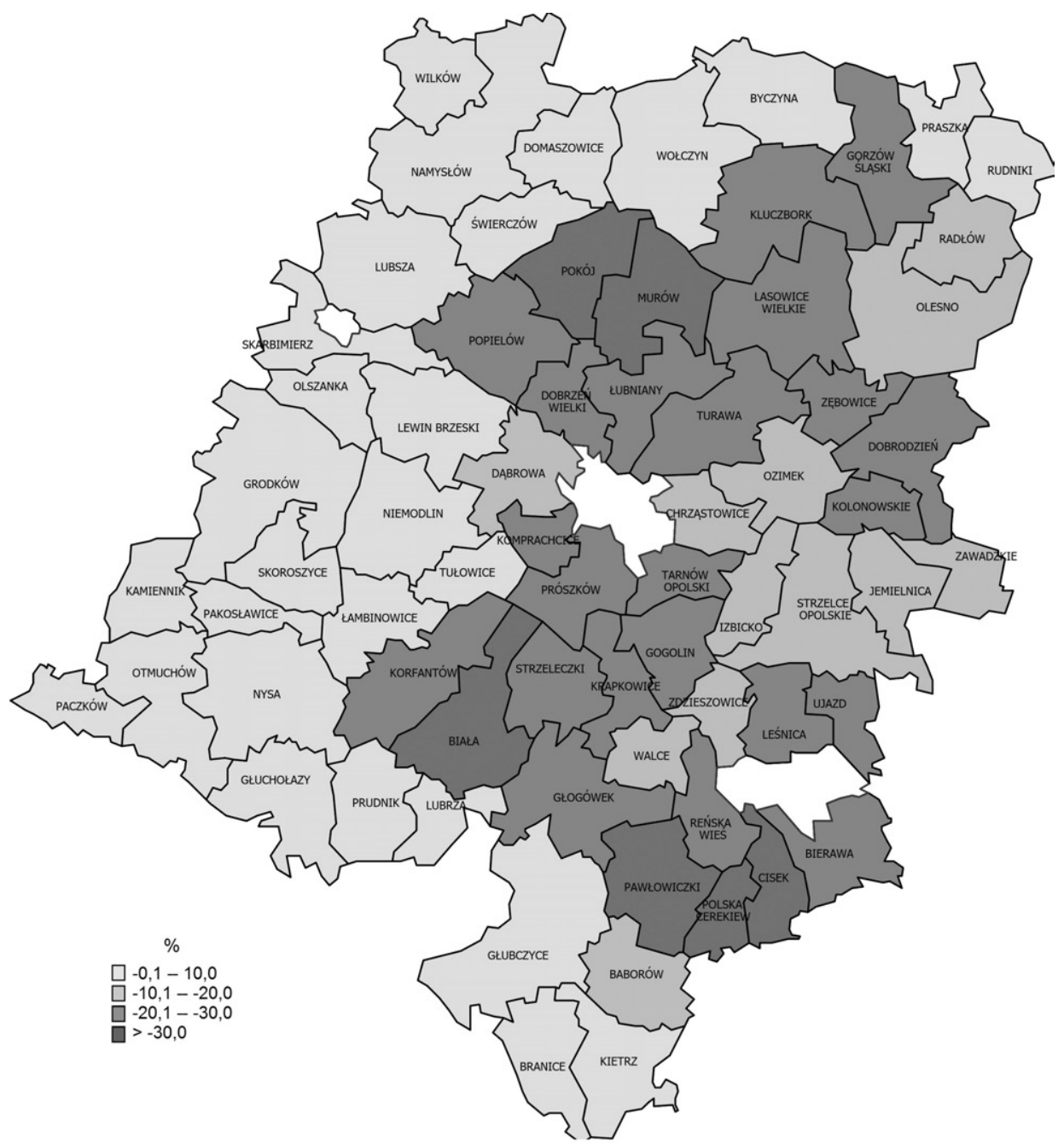

Ryc. 3. Saldo migracji zagranicznych 1974-2010 do liczby ludności w 2010 r. (\%)

Balance of international net migration rate between 1974 and 2010 in relation to population number in 2010 (\%) Źródło: opracowanie własne R. Rauziński i R. Brzozowski na podstawie Roczników Statystycznych.

Source: Own compilation by R. Rauziński and R. Brzozowski based on Statistical Yearbooks 


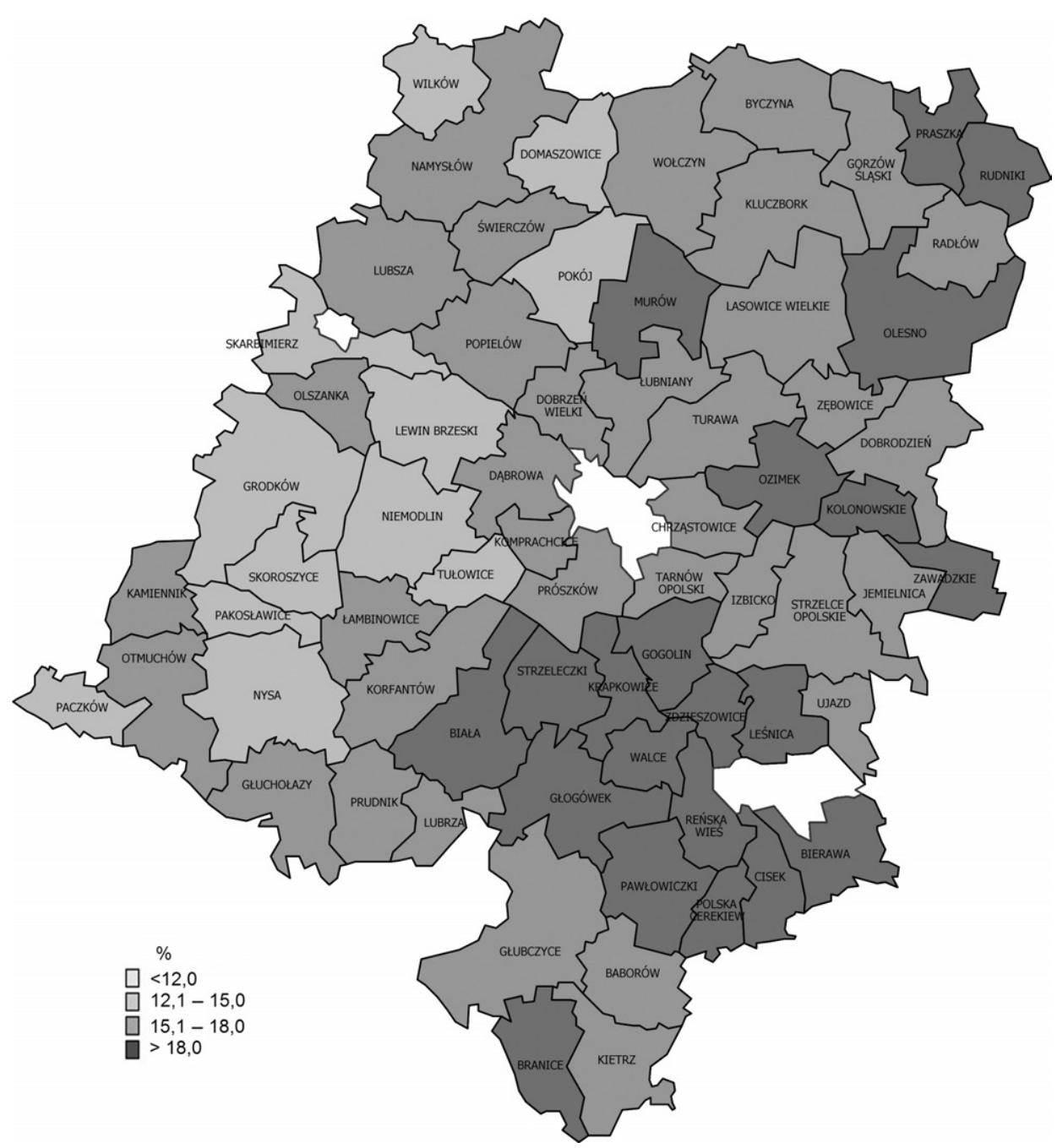

Ryc. 4. Ludność w wieku produkcyjnym na wsi w 2012 r. (\%)

Population at post-working age in rural areas in 2012 (\%)

Źródło: opracowanie własne R. Rauziński i R. Brzozowski na podstawie Roczników Statystycznych.

Source: Own compilation by R. Rauziński and R. Brzozowski based on Statistical Yearbooks

Z obrazu przedstawionego na mapach wyłania się teza o głębokim kryzysie demograficznym wsi opolskiej. W latach 1995-2010 zaszły tu głębokie zmiany w strukturze zawodowej i wykorzystaniu zasobów pracy wywołane procesami:

- wzrostu lub spadku ludności w gminach,

- defeminizacji wsi i równocześnie feminizacji zatrudnienia w rolnictwie,

- starzenia się ludności wiejskiej i zawodowo czynnej w rolnictwie,

- wzrostu „marginalnych” zasobów pracy w rolnictwie,

- spadku dojazdów do pracy do miast,

- niskiego poziomu wykształcenia rolniczego ludności wsi, 
- wzrostu bezrobocia wśród ludności wiejskiej,

- dezaktywizacji zawodowej ludności wiejskiej,

- stałego wzrostu liczby ludności pozarolniczej na wsi,

- ograniczenia wzrostu warstwy chłopsko-robotniczej i gospodarstw chłopsko-robotniczych,

- stałego nacisku młodzieży wiejskiej na nierolniczy rynek pracy i zarysowującego się bezrobocia,

- masowej migracji ze wsi do miast i migracji zagranicznych,

- bezwzględnego spadku liczby ludności i zasobów pracy w rolnictwie i poza rolnictwem (por. m.in. Szczygielski 2012, 2013; Rauziński 2012; Dybowska 2013, 2014; Heffner i Solga 2014).

Wśród pierwszoplanowych problemów wsi opolskiej lat 90. znalazły się kwestie związane z powstałym bezrobociem, stabilizacją struktur zatrudnienia w rolnictwie, ograniczonym odpływem młodzieży, masowymi migracjami ludności do pracy oraz niskim poziomem wykształcenia młodzieży wiejskiej (por. Szczygielski 2013). W ostatnich latach pogłębiały się też dysproporcje przestrzenne w stopniu wykorzystania zasobów pracy w rolnictwie, szczególnie gromadzenia się zbędnych zasobów pracy w drobnych gospodarstwach rolnych. Ukryte bezrobocie agrarne na wsi opolskiej nie ma charakteru masowego, ale objawia się dużą ilością „marginalnych” zasobów pracy.

\section{Specyfika demograficzna wsi opolskiej}

Obecnie wieś opolska charakteryzuje się tzw. „anomalią opolską”, co wyraża się bardzo wysokim odsetkiem ludności wiejskiej nierolniczej (70\%), masowymi dojazdami do pracy (35\% zasobów pracy), liczną warstwą chłopsko-robotniczą (30\%) i rozdrobnioną strukturą agrarną oraz zaawansowanym procesem starzenia się i defeminizacją wsi oraz niskim poziomem zatrudnienia w rolnictwie (por. Heffner i Rauziński 2012).

W okresie 1995-2008 dodatni przyrost naturalny ludności miał miejsce jedynie w 8 gminach: Nysa, Dąbrowa, Komprachcice, Chrząstowice, Dobrzeń Wielki, Świerczów i Skarbimierz. Natomiast koncentracja ludności w wieku produkcyjnym wystąpiła w gminach położonych w aglomeracji opolskiej, w gminach o charakterze robotniczym i chłopsko-robotniczym w zapleczu miasta Opola: Ozimek, Chrząstowice, Tarnów Opolski, Prószków, Komprachcice, Dąbrowa, Dobrzeń Wielki, Łubniany, Lasowice Wielkie. Obszary koncentracji i wysokiego udziału ludności w wieku poprodukcyjnym (20\% i więcej) występują na obszarach zamieszkałych przez ludność śląską (gminy: Biała, Strzeleczki, Gogolin, Krapkowice, Głogówek, Walce, Zdzieszowice, Reńska Wieś i inne) jako rezultat dużej emigracji zagranicznej. W wymienionych gminach odsetek emigrantów w latach 1974-2010 w stosunku do ogólnej liczby ludności przekraczał 30\%. 
Tabela 1. Odsetek migrantów (saldo migracji zagranicznych w latach 1976-2014) w stosunku do ludności w 2014 r. w gminach wiejskich oraz na obszarach wiejskich w gminach miejsko-wiejskich w województwie opolskim

\begin{tabular}{|c|c|c|c|c|}
\hline L.p. & Gminy & $\begin{array}{c}\text { Saldo migracji } \\
\text { zagranicznych na wsi } \\
\text { w latach 1976-2014 }\end{array}$ & $\begin{array}{l}\text { Liczba ludności na wsi } \\
\text { w } 2014 \text { r. }\end{array}$ & $\begin{array}{l}\text { Odsetek } \\
\text { migrantów (saldo } \\
\text { migracji do ogółu } \\
\text { ludności) }\end{array}$ \\
\hline & OGÓŁEM & -80320 & 480240 & 16,7 \\
\hline 1. & Polska Cerekiew & -2409 & 4213 & 57,2 \\
\hline 2. & Biała & -3845 & 8297 & 46,3 \\
\hline 3. & Pawłowiczki & -3558 & 7802 & 45,6 \\
\hline 4. & Cisek & -2354 & 5790 & 40,7 \\
\hline 5. & Pokój & -2151 & 5305 & 40,5 \\
\hline 6. & Murów & -2134 & 5546 & 38,5 \\
\hline 7. & Prószków & -2308 & 7129 & 32,4 \\
\hline 8. & Komprachcice & -3570 & 11093 & 32,2 \\
\hline 9. & Reńska Wieś & -2394 & 8241 & 29,0 \\
\hline 10. & Bierawa & -2223 & 7829 & 28,4 \\
\hline 11. & Strzeleczki & -2118 & 7468 & 28,4 \\
\hline 12. & Kolonowskie & -733 & 2608 & 28,1 \\
\hline 13. & Leśnica & -1479 & 5276 & 28,0 \\
\hline 14. & Kluczbork & -3220 & 12195 & 26,4 \\
\hline 15. & Krapkowice & -1673 & 6401 & 26,1 \\
\hline 16. & Zębowice & -970 & 3733 & 26,0 \\
\hline 17. & Dobrzeń Wielki & -3786 & 14580 & 26,0 \\
\hline 18. & Korfantów & -1872 & 7283 & 25,7 \\
\hline 19. & Gorzów Śląski** & -1179 & 4728 & 24,9 \\
\hline 20. & Głogówek & -1895 & 7918 & 23,9 \\
\hline 21. & Popielów & -1903 & 8126 & 23,4 \\
\hline 22. & Lasowice Wielkie & -1621 & 6930 & 23,4 \\
\hline 23. & Łubniany & -2257 & 9723 & 23,2 \\
\hline 24. & Turawa & -2250 & 9700 & 23,2 \\
\hline 25. & Tarnów Opolski & -2229 & 9645 & 23,1 \\
\hline 26. & Gogolin & -1347 & 5913 & 22,8 \\
\hline 27. & Ujazd & -1044 & 4617 & 22,6 \\
\hline 28. & Strzelce Opolskie & -2882 & 12821 & 22,5 \\
\hline 29. & Dobrodzień** & -1352 & 6257 & 21,6 \\
\hline 30. & Walce & -1191 & 5580 & 21,3 \\
\hline 31. & Chrząstowice & -1368 & 6752 & 20,3 \\
\hline 32. & Olesno** & -1712 & 8550 & 20,0 \\
\hline 33. & Izbicko & -1051 & 5408 & 19,4 \\
\hline
\end{tabular}




\begin{tabular}{|c|c|c|c|c|}
\hline 34. & Dąbrowa & -1785 & 9590 & 18,6 \\
\hline 35. & Baborów & -561 & 3161 & 17,7 \\
\hline 36. & Ozimek & -1886 & 10766 & 17,5 \\
\hline 37. & Zawadzkie & -726 & 4266 & 17,0 \\
\hline 38. & Zdzieszowice & -672 & 4209 & 16,0 \\
\hline 39. & Jemielnica & -1120 & 7167 & 15,6 \\
\hline 40. & Radłów** & -534 & 4411 & 12,1 \\
\hline 41. & Wołczyn & -753 & 7946 & 9,5 \\
\hline 42. & Branice & -614 & 7946 & 9,5 \\
\hline 43. & Niemodlin & -451 & 6873 & 6,6 \\
\hline 44. & Łambinowice & -492 & 7734 & 6,4 \\
\hline 45. & Lubrza & -196 & 4360 & 4,5 \\
\hline 46. & Lewin Brzeski & -281 & 7449 & 3,8 \\
\hline 47. & Byczyna & -210 & 5851 & 3,6 \\
\hline 48. & Prudnik & -185 & 6159 & 3,0 \\
\hline 49. & Głuchołazy & -285 & 10401 & 2,7 \\
\hline 50. & Świerczów & -89 & 3480 & 2,6 \\
\hline 51. & Tułowice* & -110 & 5254 & 2,1 \\
\hline 52. & Kietrz & -101 & 5114 & 2,0 \\
\hline 53. & Głubczyce & -195 & 10101 & 1,9 \\
\hline 54. & Otmuchów & -156 & 8852 & 1,8 \\
\hline 55. & Paczków & -87 & 5312 & 1,6 \\
\hline 56. & Skoroszyce & -88 & 6341 & 1,4 \\
\hline 57. & Lubsza & -115 & 9026 & 1,3 \\
\hline 58. & Nysa & -151 & 13221 & 1,1 \\
\hline 59. & Grodków & -114 & 10804 & 1,1 \\
\hline 60. & Olszanka & -43 & 4981 & 0,9 \\
\hline 61. & Skarbimierz & -60 & 7852 & 0,8 \\
\hline 62. & Domaszowice & -27 & 3687 & 0,7 \\
\hline 63. & Kamiennik & -26 & 3611 & 0,7 \\
\hline 64. & Namysłów & -66 & 9646 & 0,7 \\
\hline 65. & Wilków & -23 & 4565 & 0,5 \\
\hline 66. & Rudniki** & -22 & 8298 & 0,3 \\
\hline 67. & Praszka** & -13 & 5855 & 0,2 \\
\hline 68. & Pakosławice & -5 & 3641 & 0,1 \\
\hline
\end{tabular}

* powstała z dniem 01.01.1992 $\mathrm{r}$.

** włączono do województwa z dniem 01.01.1998 r., brak danych za lata 1976-1997.

*** z dniem 01.01.2004 r. wyodrębniono miasto Prószków.

Źródło: R. Brzozowski, R. Rauziński - obliczenia własne na podstawie roczników statystycznych województwa opolskiego i roczników demograficznych GUS, NSP 2002. 
Współczesna sytuacja demograficzna wsi oraz prognozy jej rozwoju na lata 2035 i 2050 mają w dużym stopniu charakter ostrzegawczy i stawiają przed koncepcją rozwoju obszarów wiejskich szereg złożonych zagadnień, które należy rozpatrywać w różnych scenariuszach rozwoju. Przekroczenie pewnych granic optymalnych procesów demograficznych (zaburzenia w reprodukcji ludności, nasilenie się deformacji demograficznych, nadmierne migracje ze wsi, nadwyżki pracy w rolnictwie, pogorszenie się zdrowia społeczeństwa, nadmierne migracje zagraniczne, bezrobocie itp.) osłabi możliwości harmonijnego rozwoju wsi. Do podstawowych kwestii, które należy uwzględnić przy formułowaniu zarysu koncepcji rozwoju wsi należy kryzys demograficzny. Wyrazem tego kryzysu jest niski poziom reprodukcji ludności, który od szeregu lat jest niekorzystny. Współczynniki reprodukcji ludności brutto i netto wskazują, że Śląsk Opolski znalazł się w obszarze zawężonej reprodukcji. Liczba urodzeń na wsi wyraźnie spada (w 1985 r. - 10,2 tys., w 1990 r. - 7,2 tys.; w 2013 r. - 4,3 tys.).

Przejawem głębokiego kryzysu demograficznego wsi jest jej wyludnianie się. Oznacza to, że cały przyrost naturalny ludności został „skonsumowany” przez emigrację zagraniczną lub wewnętrzną (por. ryc. 5-7).

W latach 1950-2011 zmieniła się struktura ludności według źródeł utrzymania, przy czym zasadniczo wzrósł udział utrzymujących się z innych niż rolnicze form zatrudnienia (tab. 2), pojawiła się również siła robocza z zagranicy (Kubiciel-Lodzińska 2013).

Tabela 2. Ludność wiejska Śląska Opolskiego utrzymująca się ze źródeł pozarolniczych w latach 1950-2011

\begin{tabular}{|c|c|}
\hline Rok & Odsetek \\
\hline 1950 & 41,5 \\
1960 & 48,3 \\
1970 & 59,0 \\
2011 & 71,1 \\
\hline
\end{tabular}

Źródło: oprac. własne na podstawie danych GUS.

Procesy demograficzne na wsi opolskiej wiążą się ściśle z wieloma dziedzinami życia społecznego i gospodarczego. Wpływają na kształtowanie się polityki edukacyjnej, rynku pracy, zatrudnienia, bezrobocia, ubóstwa, wykluczenia społecznego, sytuacji mieszkaniowej, zdrowia, dochodów i wydatków ludności, patologii społecznej i innych problemów społecznych. 


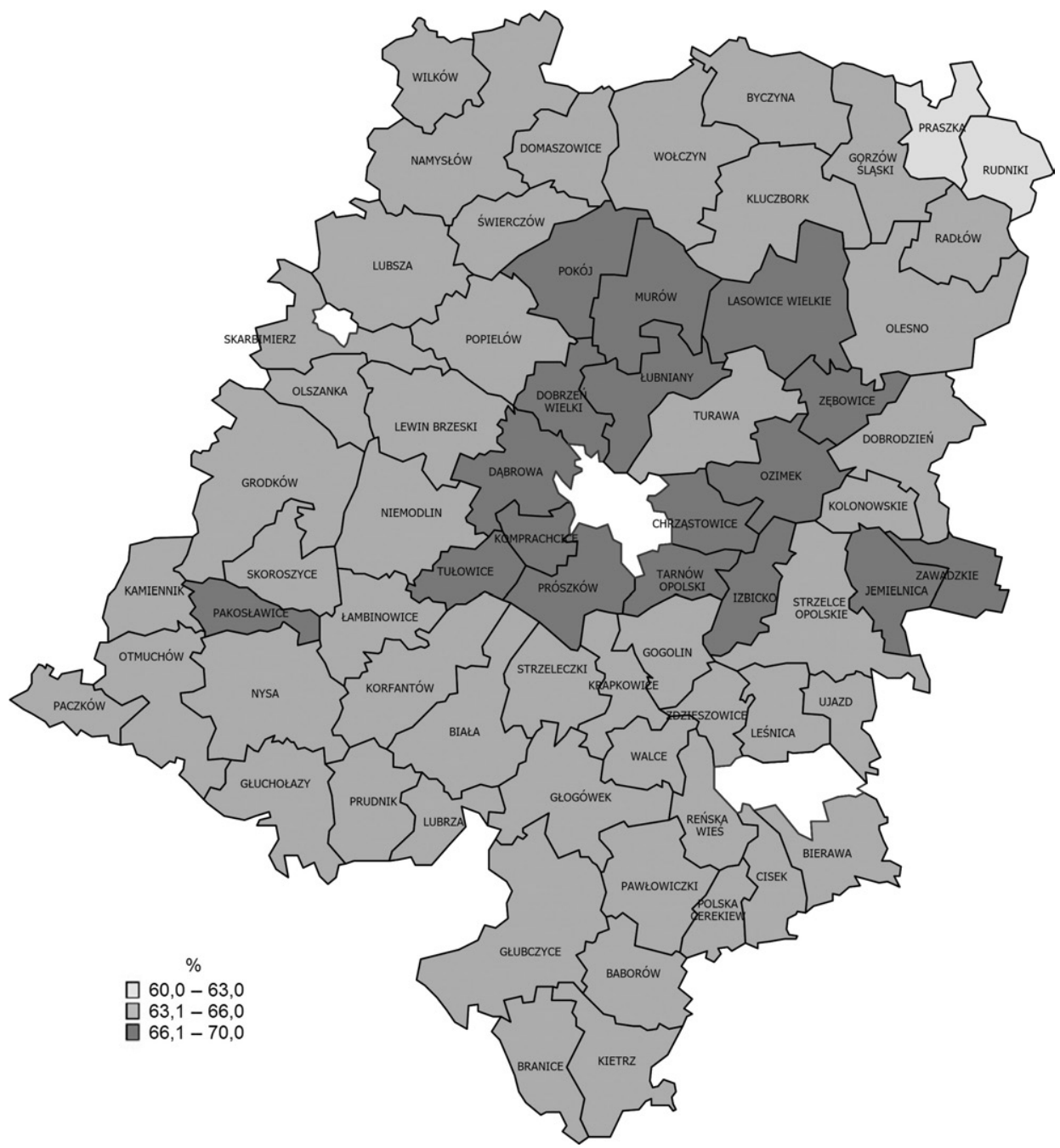

Ryc. 5. Ludność w wieku produkcyjnym na wsi w 2010 r. (\%)

Population at working age in rural areas in 2010 (\%)

Źródło: opracowanie własne R. Rauziński i R. Brzozowski na podstawie Roczników Statystycznych.

Source: Own compilation by R. Rauziński and R. Brzozowski based on Statistical Yearbooks 


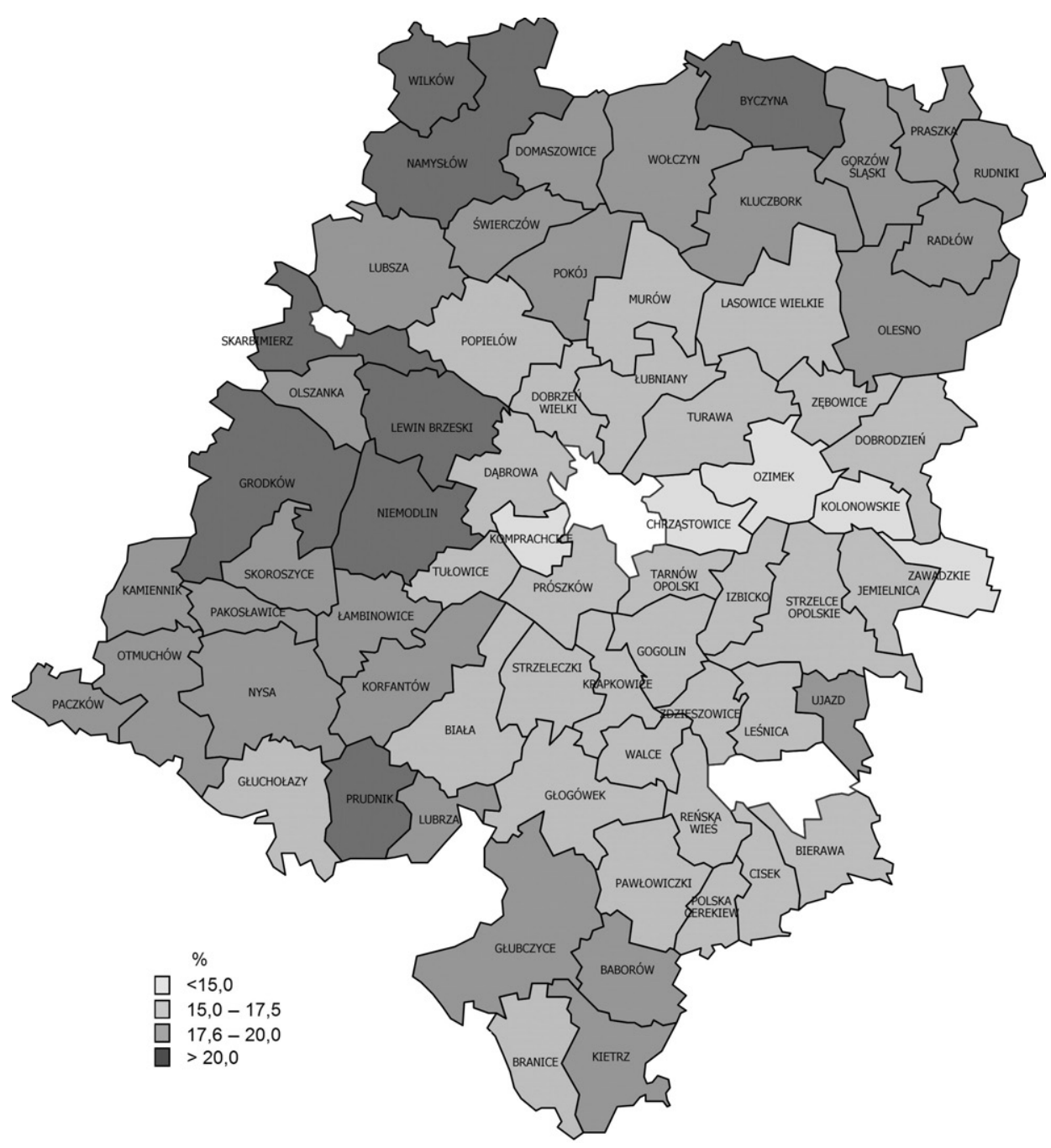

Ryc. 6. Ludność w wieku przedprodukcyjnym na wsi w 2010 r. (\%)

Population at pre-working age in rural areas in 2010 (\%)

Źródło: opracowanie własne R. Rauziński i R. Brzozowski na podstawie Roczników Statystycznych. Source: Own compilation by R. Rauziński and R. Brzozowski based on Statistical Yearbooks 


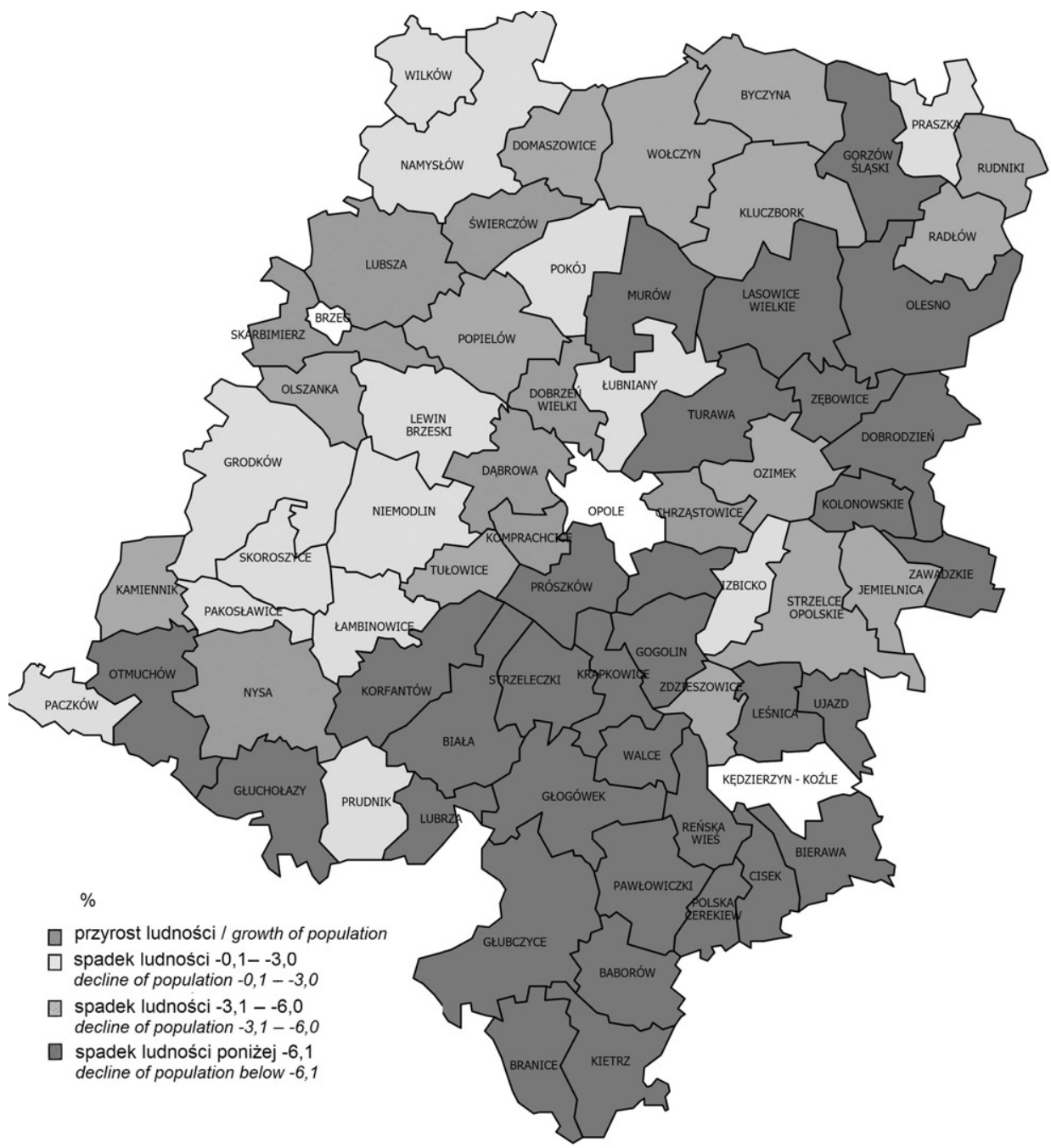

Ryc. 7. Wzrost lub spadek ludności na wsi w latach 1995-2010 (\%)

Growth or decline of population in rural areas between 1995 and 2010 (\%)

Źródło: opracowanie własne R. Rauziński i R. Brzozowski na podstawie Roczników Statystycznych

Source: Own compilation by R. Rauziński and R. Brzozowski based on Statistical Yearbooks

\section{Perspektywy zmian demograficznych na wsi opolskiej}

Zmienność struktur demograficznych wymaga zróżnicowanej lokalnej polityki społeczno-gospodarczej. Wieś opolska jest przykładem dramatycznej sytuacji demograficznej i kryzysu demograficznego o głębokich konsekwencjach społeczno-ekonomicznych. Szczególnie znaczący jest wpływ migracji zagranicznych na sytuację demograficzną wsi (zob. tab. 4).

Jak wynika z prognozy demograficznej do 2050 r., podstawową cechą przyszłego rozwoju wsi opolskiej będą głębokie zmiany w strukturze wieku w czasie (2016-2050) 
i układach przestrzennych. Starzenie się ludności wsi wysuwa się na pierwszy plan polityki społecznej realizowanej na obszarach wiejskich.

Z analizy prognozy demograficznej do 2050 r. wynikają pozytywne i negatywne procesy oraz tendencje demograficzne o charakterze doraźnym i długofalowym. Do pozytywnych tendencji demograficznych należy zaliczyć:

- wzrost przeciętnego trwania życia,

- spadek śmiertelności noworodków i ludzi młodych,

- wzrost poziomu wykształcenia ludności,

- zmniejszenie się emigracji zagranicznych,

- stabilizacja instytucji małżeńskich i rodzin,

- wzrost semiurbanizacji wsi (malejąca mobilność przestrzenna ludności, umacnia więzi społeczne),

- wzrost kapitału ludzkiego i społecznego.

Do negatywnych tendencji należy zaliczyć:

- depopulację ludności (spadek urodzeń i przyrostu naturalnego i brak zastępowalności pokoleń),

- ubytek mieszkańców wsi,

- proces starzenia się ludności i rodzin wiejskich i rolniczych,

- malejąca skłonność do zawierania małżeństw,

- wzrost liczby rozwodów,

- wzrost liczby osób niepełnosprawnych i niesamodzielnych.

Tabela 3. Prognoza demograficzna województwa opolskiego na lata 2020-2025-2050 z podziałem na miasto i wieś

\begin{tabular}{|c|c|c|c|c|}
\hline \multirow{2}{*}{\multicolumn{2}{|c|}{ Treść }} & \multicolumn{3}{|c|}{ Rok } \\
\hline & & 2020 & 2025 & 2050 \\
\hline \multicolumn{2}{|c|}{ Liczba ludności wg Prognozy GUS z 2014 (w tys.) } & 966,6 & 935,9 & 744,6 \\
\hline \multicolumn{2}{|l|}{ Liczba ludności miast (w tys.) } & 498,1 & 478,0 & 359,6 \\
\hline \multicolumn{2}{|l|}{ Liczba ludności wsi (w tys.) } & 468,5 & 457,9 & 384,6 \\
\hline \multicolumn{2}{|l|}{ Współczynnik dzietności } & 1,01 & 1,17 & 1,35 \\
\hline \multicolumn{2}{|l|}{ Średni wiek rodzenia } & 29,52 & 29,95 & 31,4 \\
\hline \multirow[t]{2}{*}{ Oczekiwana długość życia: } & - mężczyzn & 75,3 & 76,6 & 82,5 \\
\hline & - kobiet & 82,1 & 83,3 & 87,4 \\
\hline \multirow[t]{2}{*}{ Saldo migracji: } & - wewnętrznych & -557 & -515 & -466 \\
\hline & - zewnętrznych & -1800 & -1697 & -1491 \\
\hline \multicolumn{2}{|l|}{ Urodzenia } & 7092 & 6382 & 4560 \\
\hline \multicolumn{2}{|l|}{ Zgony } & 10542 & 10569 & 10683 \\
\hline \multicolumn{2}{|l|}{ Przyrost naturalny } & -3450 & -4187 & -6123 \\
\hline \multicolumn{2}{|c|}{ Odsetek ludności w wieku 0-17 } & 15,3 & 14,8 & 12,2 \\
\hline \multicolumn{2}{|c|}{ Odsetek ludności w wieku 18-55/60 } & 64,2 & 62,5 & 55,3 \\
\hline \multicolumn{2}{|l|}{ Odsetek ludności w wiek 60+ } & 20,5 & 22,7 & 32,5 \\
\hline
\end{tabular}

Źródło: Prognoza GUS 2014, Warszawa. 
Prognoza GUS dla województwa opolskiego do 2050 r. jako punkt wyjścia przyjmuje stan rzeczywisty ludności (1004,4 tys. osób) w dniu 31 grudnia 2013 r. Prognoza dla powiatów jest spójna z obowiązującą od 01.10.2014 r. prognozą dla Polski i województw do 2050 r. Niewielkie różnice wynikają z zaokrągleń. Prognoza ma strategiczne znaczenie dla dalszego rozwoju Opolszczyzny i ma charakter ostrzegawczy. Prawdopodobieństwo jej realizacji jest duże z uwagi na brak zastępowalności pokoleń i niską płodność oraz wzrost znaczenia migracji zagranicznych i wewnętrznych ludności wiejskiej. Niekorzystna sytuacja demograficzna wsi powoduje też zwiększenie dysproporcji terytorialnych w zakresie edukacji, napięć na rynku pracy oraz zrównoważonego rozwoju obszarów wiejskich. Prognoza demograficzna ludności woj. opolskiego i jej obszarów wiejskich do 2050 r. jest niekorzystna, gdyż charakteryzuje się ubytkiem liczby ludności o 259,9 tys. osób czyli o 25,9\%, przy czym proces ten stopniowo będzie narastał (zob. tab. 4).

Tabela 4. Prognoza spadku liczby ludności województwa opolskiego w latach 2016-2050

\begin{tabular}{|c|c|}
\hline \multicolumn{1}{|c|}{ Lata } & Liczba osób \\
\hline $2016-2020$ & -27881 \\
$2021-2025$ & -30771 \\
$2026-2030$ & -33824 \\
$2031-2035$ & -36880 \\
$2036-2040$ & -39322 \\
$2041-2045$ & -40576 \\
$2046-2050$ & -40663 \\
\hline Razem 2016-2050 & -249917 \\
\hline
\end{tabular}

Źródło: Obliczenia własne na podstawie Prognozy ludności na lata 2014-2050, GUS 2014.

Ubytek liczby ludności miast i wsi związany będzie z głębokimi zmianami struktury wieku ludności. Gwałtowny spadek liczby urodzeń od 1984 r. (19,5 tys. osób) do 2012 r. (8,9 tys.) spowodował spadek liczebności roczników wchodzących w wiek prokreacji i zawierania małżeństw. Jest to tendencja trwała, powodująca systematyczne zmniejszanie się liczby ludności województwa opolskiego do 2050 r. Współczynniki dzietności nie zapewniają prostej zastępowalności pokoleń. W 2020 r. liczba ludności województwa opolskiego wyniesie 966,6 tys. osób, w 2030 r. - 902 tys., w 2040 r. - 825,8 tys., w 2050 r, - 744,6 tys. Do 2050 r. spadnie udział ludności w wieku przedprodukcyjnym z 16,3\% w 2013 r. do 12,2\% w 2050 r., w wieku produkcyjnym z 65,1\% do 55,3\%, a w wieku poprodukcyjnym wzrośnie z $18,6 \%$ do 32,5\%.

Ogółem w województwie opolskim przewidywany jest w latach 2013-2050 systematyczny spadek liczby ludności o ponad $1 / 4$ (25,9\%). W powiecie brzeskim będzie on wynosił 21,5\%, głubczyckim 32,4\%, kędzierzyńsko-kozielskim 31,2\%, kluczborskim 28,4\%, krapkowickim $28,7 \%$, namysłowskim 19,9\%, nyskim 31,1\%, oleskim $27,0 \%$, opolskim $14,5 \%$, prudnickim 30,5\% i strzeleckim 26,7\%. We wszystkich powiatach zmniejsza się populacja, a w niektórych znacznie (ponad 30\% w głubczyckim i kędzierzyńsko-kozielskim). Wyludnianie się oraz proces dezurbanizacji staje się trwałym elementem sytuacji demograficznej województwa, a w powiązaniu z wyludnianiem się obszarów wiejskich, a szczególnie przygranicznych, stanowi czynnik ograniczający rozwój regionu. 
W latach 2013-2050 we wszystkich powiatach nastąpi ujemny przyrost naturalny (urodzenia minus zgony) i rzeczywisty (saldo migracji). Przyrost naturalny zarówno w miastach, jak i na obszarach wiejskich będzie się pogłębiał. Wyłania się problem jakości społeczeństwa, a więc jego szeroko rozumianych warunków życia i pracy oraz edukacji, zdrowia, zatrudnienia, warunków mieszkaniowych, dochodów, patologii społecznej. Jakość kapitału ludzkiego i społecznego (wykształcenie i zatrudnienie absolwentów szkół wyższych) stają się głównym zadaniem dla polityki społecznej.

\section{Prognoza demograficzna województwa opolskiego do 2050 r.}

Prognoza wskazuje, że współczynnik dzietności wzrośnie z 1,04\% w 2015 r. do 1,17\% w 2025 r. i 1,35\% w 2050 r. Pomimo pozytywnego wzrostu współczynników dzietności, liczba urodzeń będzie miała tendencje spadku. Jest to rezultatem spadku liczby kobiet w wieku prokreacji. Równocześnie średni wiek rodzenia kobiet zwiększy się z 28,91 lat w 2015 r. do 31,14 lat w 2050, długość życia mężczyzn z 74,2 do 82,5, kobiet z 81,2 do 87,4 lat.

Wiele wskazuje na to, że migracje zagraniczne będą istotnym czynnikiem wzrostu lub spadku rzeczywistego zaludnienia miast i wsi. Wyczerpanie się potencjału demograficznego województwa opolskiego nie spowoduje, że w sumie prognozowane saldo migracji zagranicznych będzie ujemne (por. Heffner i Solga 2014). Występujące tendencje w procesach migracyjnych to:

- przekształcenie części emigrantów (co najmniej 105 tys. osób) w emigrację stałą,

- dalsza emigracja czasowa jednak o tendencji malejącej,

- wzrost sieci powiązań migracyjnych,

- ograniczone powroty emigrantów,

- odpływ mobilnej młodzieży z obszarów o wysokim bezrobociu i charakterze rolniczym.

- Utrzymanie zatem więzi z emigrantami stanowi główny cel regionalnej polityki społecznej.

\section{Konkluzje}

Przeprowadzone badania, obliczenia statystyczne oraz analiza demograficzna bogatego materiału statystycznego i kartograficznego pozwalają na sformułowanie następujących tez:

- Rolnicze obszary wiejskie Śląska Opolskiego nie są w pełni wykorzystane z punktu widzenia czynnika ludzkiego. Badania potwierdziły hipotezę, że czynnik ludzki w rolnictwie słabnie (powstają poważne deformacje demograficzne m.in. z powodu migracji).

- Struktury demograficzne ludności obszarów wiejskich województwa są silnie zróżnicowane przestrzennie. Przyrost i rozmieszczenie ludności i zasobów pracy były nierównomierne w czasie i przestrzeni. Proces ten ma cechy trwałości i odegra znaczną rolę w rozwoju rolnictwa. Powstają obszary wiejskie o poważnych zagrożeniach demograficznych.

- Istniejąca struktura zawodowa ludności wsi jest wadliwa i charakteryzuje się licznymi dysproporcjami na lokalnych rynkach pracy. 
- W rolnictwie zachodziły niekorzystne zmiany w strukturze demograficznej, zawodowej i strukturze gospodarujących (starzenie się, spadek zasobów pracy, deformacje demograficzne), emigracja zagraniczna, niskie zatrudnienie kadr kwalifikowanych. Nastąpił spadek potencjału pracy. Powstają obszary problemowe (zagrożeń) o znacznym, przekraczającym przyrost naturalny, odpływie ludności w długim okresie czasu.

- Występująca selektywność migracji (z punktu widzenia płci, wieku i wykształcenia) prowadzi do nieodwracalnych deformacji demograficznych.

- Rozwój rolnictwa i gospodarki wiejskiej wymaga co najmniej prostej reprodukcji ludności na wsi opolskiej na okres perspektywiczny. Dalszy odpływ ludności z rolnictwa przy obecnej strukturze agrarnej stopnia mechanizacji prac może wpłynąć niekorzystnie na wzrost produkcji rolnej. Polityka zatrudnienia winna wpływać na optymalizację struktur zatrudnienia ludności w rolnictwie, głównie przez rozwój usług dla rolnictwa.

- Migracje zagraniczne ze wsi spowodowały trwałe i nieodwracalne straty biologiczne w zasobach pracy.

- Kierowanie procesami zatrudnienia w rolnictwie wymaga nowego spojrzenia na problem szkolnictwa rolniczego, konieczna jest też kompleksowa rozbudowa systemu orientacji zawodowej, poradnictwa itp.

- Istniejący podział pracy wśród mieszkańców wsi ma wszelkie cechy trwałości. Trudno bowiem zgodzić się z poglądem, że szybkie zmiany struktury agrarnej wyzwolą bezrobocie na wsi.

- Miejskie rynki pracy związane będą z nieustannym narastaniem skupisk ludności w gminach położonych w zapleczu miast.

- Rozwój ludności pozarolniczej na wsi wymaga wydzielenia stref podmiejskich lub wiejskich dla celów budownictwa mieszkaniowego. Równocześnie będzie on wpływać na stały wzrost potrzeb w zakresie komunikacji.

- Przygotowanie zawodowe młodzieży do pracy w rolnictwie stanowi węzłowy i trudny do rozwiązania problem restrukturyzacji rolnictwa.

\section{Literatura}

Bański J., 2014, Perspektywy rozwoju polskiej wsi-wybrane zagadnienia, Wieś i Rolnictwo, 4 (165), s. $13-25$.

Dybowska J., 2014, Depopulacja na obszarach wiejskich województwa opolskiego w latach 2002-2011, Journal of Agribusiness and Rural Development, 2 (32), s. 59-68.

Dybowska J., 2013, Przemiany demograficzne w regionie o nasilonej migracji zagranicznej na przykładzie województwa opolskiego, Uniwersytet Opolski, Opole.

Dybowska J., 2012, Migracja a stan ludności w województwie opolskim, [w:] R. Rauziński, T. Sołdra-Gwiżdż (red.), Społeczeństwo Ślqqska Opolskiego 1945-2011-2035 - aspekty społeczne, demograficzne i rynku pracy, Ministerstwo Rozwoju Regionalnego, Opole-Warszawa.

Heffner K., 1990, Przebieg procesów depopulacyjnych na Opolszczyźnie, [w:]K. Heffner (red.), Procesy wyludniania się wsi w regionie opolskim, PIN - Instytut Śląski w Opolu, Opole, s. 7-50.

Heffner K., Rauziński R., 2012, Region migracyjny, jego cechy i ewolucja w Polsce na przykładzie Ślqska Opolskiego, [w:] P. Kaczmarczyk, M. Lesińska (red.), Krajobrazy migracyjne Polski, Ośrodek Badań nad Migracjami Uniwersytetu Warszawskiego, Warszawa, s. 61-84. 
Heffner K., Solga B., 2014, Ewolucja procesów migracyjnych na Ślq̨sku Opolskim w kontekście europejskim, klasyfikacja głównych tendencji na tle przemian demograficznych, Studia Śląskie, 75, Opole, s. 71-88.

Jończy R., 2010, Migracje zagraniczne z obszarów wiejskich województwa opolskiego po akcesji Polski do Unii Europejskiej. Wybrane aspekty ekonomiczne i demograficzne, Wydawnictwo Instytut Śląski, Opole-Wrocław.

Kubiciel-Lodzińska S., 2013, Obecność zagranicznej siły roboczej w rolnictwie w Polsce jako konsekwencja zmian następujqcych na wsi (ze szczególnym uwzględnieniem woj. opolskiego), [w:] K. Heffner (red.), Rozwój obszarów wiejskich w Polsce a polityka spójności Unii Europejskiej: Stare problemy i nowe wyzwania ze szczególnym uwzględnieniem woj. opolskiego, Studia KPZK PAN, 154, Warszawa, s. 138-150.

Prognoza ludności na lata 2014-2050, 2014, Główny Urząd Statystyczny, Warszawa.

Rauziński R., 1990, Ludność na Ślq̨sku 1945-1990, WSI, Opole.

Rauziński R., 2012, Śląsk Opolski regionem kryzysu demograficznego, [w:] R. Rauziński, T. Sołdra-Gwiżdż, Społeczeństwo Ślq̨ska Opolskiego 1945-2011-2035 - aspekty społeczne, demograficzne i rynku pracy, Rządowa Rada Ludnościowa, PIN - Instytut Śląski w Opolu, Urząd Marszałkowski Województwa Opolskiego, Opole-Warszawa, s. 27-63.

Rauziński R., Szczygielski K., 2008, Ślq̨ska ludność rodzima w strukturze demograficznej i społecznej Śląska Opolskiego wczoraj i dziś, Wydawnictwa Wyższej Szkoły Zarządzania i Administracji, Opole.

Rauziński R., Szczygielski K., 2015, Prognoza ludności dla województwa opolskiego do 2050 roku. Wnioski w kontekście prowadzenia polityki regionalnej oraz wsparcia odnowy demograficznej województwa opolskiego, Ekspertyza w ramach projektu Opolskie Obserwatorium Terytorialne. Wzmocnienie systemu monitorowania polityk publicznych (maszynopis niepublikowany).

Wójcik M. (red.), 2014, Regionalny wymiar przemian polskiej wsi-aspekty społeczne i środowiskowe, Studia Obszarów Wiejskich, 34, PTG, IGiPZ PAN, Warszawa.

Rosner A., 2012, Aktualne tendencje zmian zaludnienia obszarów wiejskich, [w:]A. Rosner (red.), Rozwój wsi i rolnictwa w Polsce. Aspekty przestrzenne i regionalne, Instytut Rozwoju Wsi i Rolnictwa PAN, Warszawa.

Solga B., 2002, Migracje polsko-niemieckie i ich konsekwencje społeczno-ekonomiczne na obszarach wiejskich Śląska Opolskiego, PIN - Instytut Śląski w Opolu, Opole.

Solga B., 2015, Migracje zagraniczne $i$ ich znaczenie w kontekście prognozowanych przemian demograficznych w Polsce i w województwie opolskim, [w:] M. Mazurkiewicz, A. Franke, T. Siwek (red.), Colloquium Opole. 10 lat razem w Unii Europejskiej. Zagrożenia i szanse, PIN - Instytut Śląski w Opolu, Opole, s. 141-153.

Szczygielski K., 2010, Przestrzenne zróżnicowanie ludności województwa opolskiego w kontekście etnicznym jako potencjalne uwarunkowanie rozwoju regionalnego, PIN - Instytut Śląski w Opolu, Opole.

Szczygielski K., 2010, Struktura przestrzenna ludności województwa opolskiego, [w:] M. Lis, K. Szczygielski, L. Drożdż (red.), Województwo opolskie 1950-2010, Stowarzyszenie Instytut Śląski, PIN - Instytut Śląski w Opolu, Opole, s. 99-119.

Szczygielski K., 2012, Społeczno-gospodarcze konsekwencje prognozy demograficznej do 2035 roku - aspekt etniczny, [w:] R. Radziński, T. Sołdra-Gwiżdż (red.), Społeczeństwo Ślqska Opolskiego 1945-2011-2035 - aspekty społeczne, demograficzne i rynku pracy, Rządowa rada Ludnościowa, PIN - Instytut Śląski w Opolu, Urząd Marszałkowski Województwa Opolskiego, Opole-Warszawa, s. 64-78. 
Szczygielski K., 2013, Demograficzne uwarunkowania realizacji Regionalnego Programu Operacyjnego. Casus - region opolski, [w:] K. Heffner (red.), Rozwój obszarów wiejskich w Polsce a polityka spójności Unii Europejskiej: Stare problemy i nowe wyzwania ze szczególnym uwzględnieniem woj. opolskiego, Studia KPZK PAN, 154, Warszawa, s. 117-128.

\section{Summary}

The principal objective of this paper is to analyze social, demographic and professional transformation of rural population inhabiting the Opolskie Voivodship in the period of 1995-2011. The study is mainly based on the CSO data from the National Census. The article provides analysis concerning potential effects of these phenomena in the perspective of 2035 and 2050. It has been proven that the thesis of a deep demographic crisis of this region's rural areas is justified. There have occurred meaningful changes in the professional structure of rural population and the use of labor resources is highly varied and complex, both in terms of time and space. Rural areas presenting agricultural function in the Opolskie Voivodship are not completely utilized considering their demographic potential, and conducted research has confirmed that the human factor in agriculture has been weakening (demographic deformations have occurred mainly due to permanent migration outflow). 



\section{Informacja dla Autorów}

Studia Obszarów Wiejskich to wydawnictwo publikujące oryginalne opracowania naukowe z zakresu geografii społeczno-ekonomicznej, geografii wsi i przestrzennego zagospodarowania kraju w języku polskim lub/i angielskim. Zapraszamy Autorów do nadsyłania wartościowych artykułów. Przestrzeganie poniższych zaleceń formalnych usprawni prace redakcyjne i przyczyni się do szybszej publikacji nadsyłanych materiałów.

Uwagi ogólne. Zgłoszenie przez autora(ów) tekstu do Studiów Obszarów Wiejskich oznacza, że nie jest on przewidziany do druku w innym wydawnictwie. Jest także jednoznaczne z wyrażeniem zgody na jego rozpowszechnianie przez IGiPZ PAN w formie drukowanej i elektronicznej z wykorzystaniem licencji Creative Commons: uznanie autorstwa, 3.0 Polska.

Podstawowym sposobem przekazania materiałów do druku jest przesłanie tekstu i załączników na płycie CD na adres wskazany przez redakcję. Tekst artykułu powinien być napisany zwięźle, ale jasno, przy użyciu edytora MS WORD. Objętość artykułu nie powinna przekraczać 6000 słów. Wszystkie załączniki graficzne muszą być dostarczone w formie osobnych plików. Preferowany format dla załączników graficznych: JPG, TIF, EPS.

Strona tytułowa. Na pierwszej stronie należy w kolejności umieścić: tytuł pracy w języku polskim (maksymalnie 120 znaków, tytuł pracy w języku angielskim, imię i nazwisko autora/autorów (cyfry arabskie po nazwisku, umieszczane jako indeks górny, określają odp. afiliację), afiliację, adres(y), e-mail(e), zarys treści (maksymalnie 200 słów powinien zawierać: sformułowanie celu pracy/badań, identyfikację obiektu badań, przedmiotu rozważań, istotę stosowanej metody, najważniejsze wyniki i wnioski), słowa kluczowe (podaje się nie więcej niż 5 słów kluczowych).

Tekst artykułu pisany czcionką Calibri Light 10, interlinia 1,0. Nie należy nadawać odrębnych stylów znakowych fragmenom tekstu. W tekście opracowania, przy powoływaniu się na literaturę, należy podawać nazwisko autora oraz rok publikacji, np. (Nowak 2004; Kowalski 2005, 2007) lub według A. Nowaka (2006), a przy cytowaniu również numer strony, np. według A. Nowaka (2006, s. 6). W powołaniach na więcej prac tego samego autora, które ukazały się w tym samym roku, podaje się: (Nowak 1987a, b). W przypadku wspólnej publikacji dwóch autorów podaje się: (Kowalski i Nowak 1999), a trzech i więcej autorów: (Kowalski i in. 2006).

Podziękowania - opcjonalnie oraz ewentualna informacja o źródłach finansowania publikacji i wkładzie innych podmiotów w opracowanie publikacji (zgodnie z wymogami jakościowymi i standardami etycznymi opisanymi niżej) należy zamieścić po zasadniczym tekście.

Rysunki i fotografie powinny być zamieszczone w tekście, a ponadto dołączone w postaci osobnych plików posiadających numerację zastosowaną w tekście. Wymagana jest wysoka rozdzielczość rysunków i fotografii (min. 300 dpi w plikach rastrowych JPG lub TIF). Dopuszczalne formaty wektorowe (EPS, CDR). Tytuł, objaśnienia znaków legendy i źródło w języku polskim i angielskim powinny znajdować się poza rysunkiem, w pliku tekstowym. Część tomów drukowana jest w kolorze czarno-białym. Należy upewnić się, że po zastąpieniu ew. kolorów skalą szarości i przeskalowaniu do rozmiarów maksymalnie 12,5 × 20 cm rysunki i fotografie będą wystarczająco czytelne. Zalecany krój czcionki dla napisów będących częścią grafiki (bez możliwości edycji) to Calibri.

Tabele powinny być zamieszczone w tekście. Każda tabela powinna zawierać zwięzły tytuł (u góry) w języku polskim, kolejny numer i źródło danych (u dołu). Wszystkie skróty powinny być objaśnione (tytuł, źródło i objaśnienia należy dołączyć jedynie w pliku tekstowym). W komórkach tabeli nie powinny znajdować się znaki tabulacji (Tab) ani końca akapitu (Enter) - w razie potrzeby można korzystać ze znaku wymuszonego końca wiersza (Shift+Enter). 
Spis literatury ograniczony do literatury cytowanej, w porządku alfabetycznym, należy zamieścić poniżej tekstu artykułu według poniższego wzoru:

- Artykuły w czasopismach i seriach wydawniczych:

Wójcik M., 2011, Współczesne kierunki i podejścia badawcze w geografii wsi, Przegląd Geograficzny, 83, 2, s. $163-185$.

Kulikowski R., 2013, Obszary wiejskie województwa podlaskiego w perspektywie 2050 roku, Studia Obszarów Wiejskich, 31, s. 129-142.

- Rozdziały w pracach zbiorowych:

Zegar J. S., 2014, Typy społeczno-ekonomiczne indywidualnych gospodarstw rolnych według rodzaju gmin, [w:] R. Rudnicki. M. Kluba (red.), Zintegrowany rozwój obszarów wiejskich w świetle polityki Unii Europejskiej, t. 1, Rolnictwo i Wspólna Polityka Rolna, Wydawnictwo Naukowe Uniwersytetu Mikołaja Kopernika, Toruń, s. 57-73.

- Książki

Bański J., 2006, Geografia polskiej wsi, PWE, Warszawa.

Streszczenie. Na końcu opracowania powinno być zamieszczone streszczenie w języku angielskim zweryfikowane przez native-speakera. Objętość streszczenia: około 250-400 słów.

Ocena artykułów i dopuszczenie ich do druku. Wszystkie artykuły nie spełniające powyższych zasad będą odsyłane do poprawy. Artykuły podlegają ocenie przez dwóch recenzentów. W procesie recenzowania stosowane jest rozwiązanie, w którym autor(zy) i recenzenci nie znają swoich tożsamości (tzw. "double-blind review proces"). Wynik recenzji będzie miał decydujący wpływ na możliwość opublikowania materiału w Studiach Obszarów Wiejskich. Szczegółowe zasady dotyczące recenzowania zamieszczone są na stronie internetowej czasopisma. Wersja pierwotna. Wersja papierowa i elektroniczna są tożsame, jednakże Redakcja wskazuje wersję papierową jako wersję pierwotną czasopisma.

Wymogi jakościowe i standardy etyczne. W trosce o dochowanie najwyższych standardów redakcyjnych oraz w celu zapobieżenia nierzetelności w publikacjach naukowych określanych jako tzw. ghostwriting i guestauthorship Redakcja Studiów Obszarów Wiejskich wymaga od autorów ujawniania informacji o podmiotach przyczyniających się do powstania publikacji (wkład merytoryczny, rzeczowy, finansowy etc.). W tym celu zobowiązuje się autorów do zachowania następujących standardów podczas przygotowywania tekstów składanych do publikacji: 1) w przypadku publikacji naukowych, które nie zostały wykonane samodzielnie, tzn. opracowano je we współautorstwie lub z wykorzystaniem pomocy wyspecjalizowanego podmiotu (osoby fizycznej lub prawnej), w końcowej części pracy (w punkcie: "Podziękowania") należy zawrzeć notę, w której ujawniany jest wkład poszczególnych autorów (współautorów) w powstanie publikacji (artykułu, monografii). Oznacza to konieczność podania ich afiliacji oraz kontrybucji, tj. informacji kto jest autorem koncepcji, założeń, zastosowanych metod, protokołu itp., wykorzystywanych w toku pracy badawczej - przygotowywania publikacji; główną odpowiedzialność ponosi autor zgłaszający manuskrypt. 2) Autor/współautorzy podają ponadto informację o ewentualnych źródłach finansowania publikacji, wkładzie instytucji naukowo-badawczych, stowarzyszeń i innych podmiotów w opracowanie publikacji (financial disclosure). Redakcja wydawnictwa informuje, że wszelkie przejawy nierzetelności naukowej, zwłaszcza łamania i naruszania zasad etyki obowiązujących w nauce, w tym wykryte przypadki ghostwriting, guestauthorship będą dokumentowane i oficjalnie demaskowane, włącznie z powiadomieniem odpowiednich podmiotów (instytucje zatrudniające autorów, towarzystwa naukowe, stowarzyszenia edytorów naukowych itp.). 

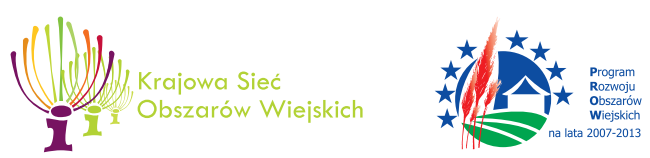

Europejski Fundusz Rolny na rzecz Rozwoju Obszarów Wiejskich: Europa inwestująca w obszary wiejskie Konferencja XXXI Seminarium Geografii Wsi: Obszary wiejskie - pierwsza dekada w Unii Europejskiej i nowa perspektywa

wspóffinansowana ze środków Unii Europejskiej w ramach Schematu III Pomocy Technicznej Programu Rozwoju Obszarów Wiejskich na lata 2007-2013 Instytucja Zarządzająca Programem Rozwoju Obszarów Wiejskich na lata 2007-2013: Minister Rolnictwa i Rozwoju Wsi

Publikacja opracowana na zlecenie Politechniki Opolskiej

\section{STUDIA OBSZARÓW WIEJSKICH}

\section{Wioletta KAMIŃSKA}

Poziom wykształcenia zasobów wiejskiej siły roboczej w Polsce. Analiza przestrzenna

\section{Jan SIKORA}

Poziom zadowolenia mieszkańców wsi z życia na wsi w świetle badań empirycznych

\section{Maria BEDNAREK-SZCZEPAŃSKA}

Wpływ konfliktu typu NIMBY na wiejską społeczność lokalną

\section{Mirosław BICZKOWSKI}

Fundusze unijne wdrażane poprzez Regionalne Programy Operacyjne jako neoendogeniczny

czynnik rozwoju obszarów wiejskich

\section{Krystian HEFFNER • Brygida KLEMENS}

Finansowanie struktur klastrowych w perspektywie 2014-2020 - wnioski dla klastrów na obszarach wiejskich

\section{Monika ZADROŻNIAK}

Rozwój Lokalny Kierowany przez Społeczność a jakość życia na obszarach wiejskich wobec koncepcji zrównoważonego rozwoju

\section{Marcin WósCIK}

Nowy paradygmat w rozwoju wiejskiej infrastruktury. Studium przypadku konkursu projektów Przyjazna wieś

\section{Małgorzata SURMACZ • Witold MAGRYŚ}

Trójsektorowość podejścia LEADER w założeniach i w praktyce wdrażania w okresie programowania 2007-2013 na przykładzie województwa śląskiego

\section{Brygida SOLGA}

Spójność strategii rozwoju gmin wiejskich województwa opolskiego ze strategią regionalną Wanda MUSIALIK

Problemy nieformalnych opiekunów seniorów w rodzinie - kwestia ważna czy mało ważna? Rozważania niearbitralne

\section{Aleksandra JEZIERSKA-THÖLE}

Zmiany w z asobach i jakości kapitału ludzkiego na obszarach wiejskich Polski i wschodnich Niemiec

\section{Marta GWIAŹDZIŃSKA-GORAJ • Sebastian GORAJ}

Ruch migracyjny na obszarach wiejskich Polski północnej

\section{Stanisława GÓRECKA • Robert SZMYTKIE • Wojciech MALESZKA}

Prognoza demograficzna dla obszarów wiejskich województwa dolnośląskiego do 2020 r.

\section{Ryszard WILCZYŃSKI}

Sytuacja rozwojowa wsi w województwie opolskim w warunkach depopulacji

\section{Joanna DYBOWSKA}

Ludność na obszarach wiejskich województwa opolskiego - przeszłość i perspektywy demograficzne

\section{Robert RAUZIŃSKI・ Kazimierz SZCZYGIELSKI}

Ludność, zatrudnienie, migracje wśród ludności wiejskiej Śląska Opolskiego w latach 1995-2017-2035 